\title{
Child Neurology: A Case of FHL1-Related Disease Presenting as Inflammatory Myopathy
}

André Macedo Serafim Silva, MD, Clara Gontijo Camelo, MD, Ciro Matsui-Júnior, MD, Rodrigo de Holanda Mendonça, MD, Lúcia Maria Campos, MD, PhD, Adriana Maluf Elias, MD, PhD, Clovis Artur Silva, MD, PhD, Umbertina Conti Reed, MD, PhD, and Edmar Zanoteli, MD, PhD

Neurology ${ }^{\circledR}$ 2021;96:e1383-e1386. doi:10.1212/WNL.0000000000011320

A 4-year-old girl, the first child of nonconsanguineous parents, with normal motor development, presented with frequent falls, difficulty getting up from the floor, and muscle pain for several months. Her initial serum creatine kinase (CK) level was $820 \mathrm{U} / \mathrm{L}$, and EMG showed a myopathic pattern. Echocardiogram and electrocardiogram were both normal. She was considered as having juvenile polymyositis by the pediatric rheumatologist, and treatment with prednisolone was initiated. At first, she presented with improvement and stabilization of signs and symptoms, but 5 months later, the weakness worsened rapidly, and she was restricted to a wheelchair, with a persistent elevated serum CK level (746 U/L). Muscle MRI showed diffuse, symmetrical, interstitial edema in the proximal and distal upper limb muscles and in glutei and thigh muscles, without fat infiltration or atrophy (figure). The diagnostic hypothesis of idiopathic inflammatory myopathy (IIM) was considered, and at the age of 5 years, she was referred to our service, with generalized weakness and severe axial involvement with loss of head control. A biceps brachii muscle biopsy was performed and showed severe dystrophic pattern, numerous necrotic fibers with macrophage reaction (CD68+ cells), lymphocyte endomysial infiltration (CD8+ cells), increased MHC-I expression, and intracytoplasmic aggregates (figure). The common antibodies for immune-mediated necrotizing myopathy (IMNM), anti-HMGCR and anti-SRP antibodies, were negative. As seronegative IMNM may occur and considering the intense edema in the muscle MRI and the significant macrophage reaction on the muscle biopsy, the possibility of inflammatory myopathy remained as the main clinical diagnosis. Monthly IV methylprednisolone and immunoglobulin were initiated and further associated with oral prednisolone and methotrexate, promoting improvement of head control and proximal weakness, and enabling her to achieve sitting ability. However, after 4 months of sustained response, she started getting worse again, becoming refractory to immunosuppressive treatment. At that time, mycophenolate mofetil and rituximab were added to treatment, but she did not respond.

Due to this unfavorable course, we decided to perform a new lower limb MRI, which depicted profound atrophy with partial fat substitution, notably in the posterior compartments, with slight hypersignal in T2 sequences (figure). A reanalysis of muscle biopsy, with menadionenitro-blue-tetrazolium (NBT) stain, showed that cytoplasmic aggregates were reducing bodies (figure). Whole exome sequencing was performed, demonstrating a de novo heterozygous pathogenic missense variant in the FHL1 (c.302G>A; p.Cys101Tyr), and the diagnosis of reducing body myopathy (RBM) was concluded. The disease progressed, and the patient worsened to total functional dependency: restricted to bed, severe proximal weakness, distal contractures, diaphragm paralysis, tracheostomy with continuous mechanical ventilation, and gastrostomy. Her treatment was then reviewed, and immunosuppressive and biological agents were progressively tapered.

\section{Discussion}

Inherited myopathies in children are usually slowly progressive diseases, even severe muscular dystrophy (MD). On the other hand, acute and subacute progression is suggestive of IIM. The

\author{
Correspondence \\ Dr. Silva \\ andremacedo@usp.br
}



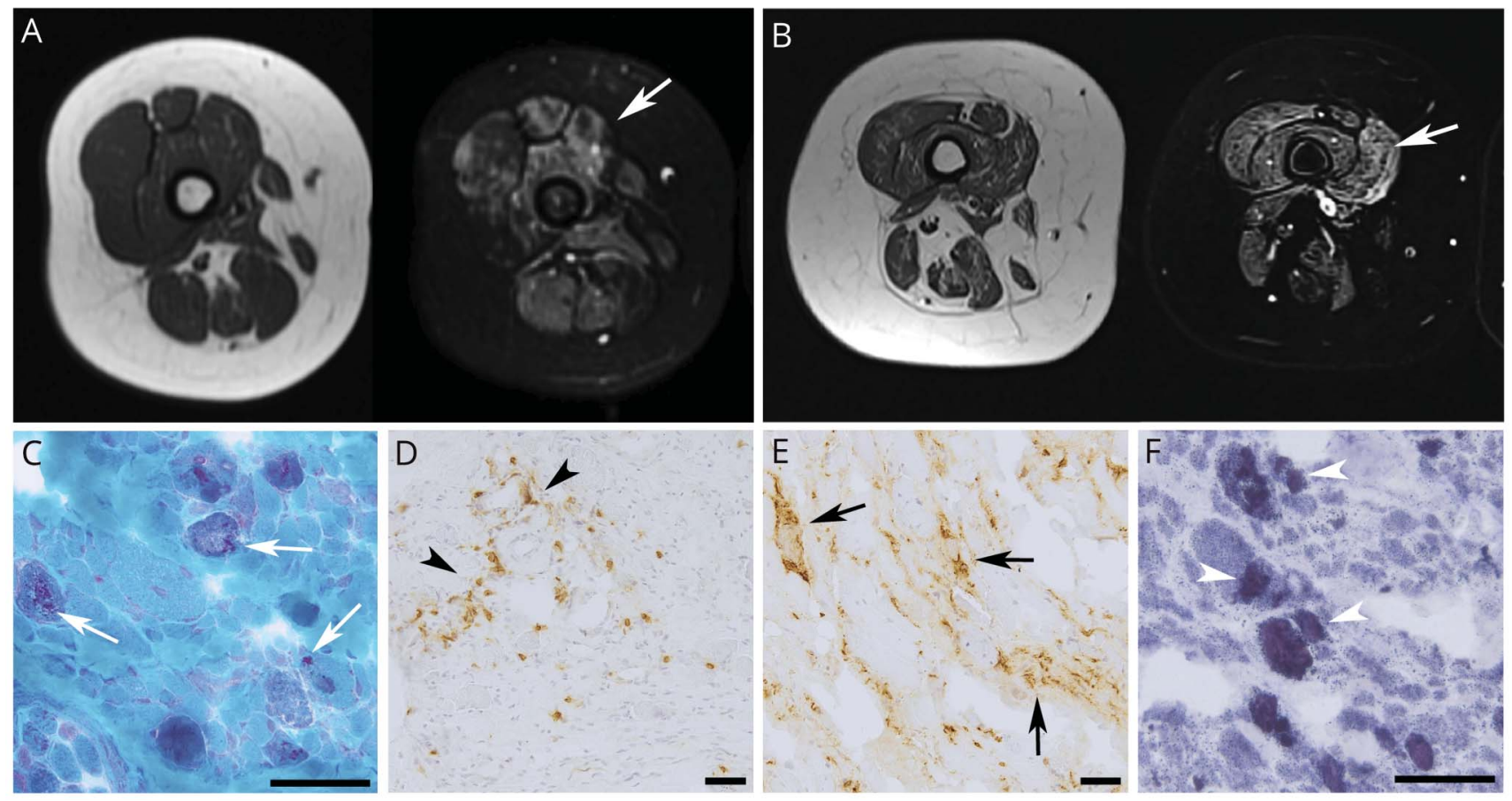

(A) The first MRI shows an axial T1-weighted sequence (left) with a relatively preserved muscle signal in the thigh muscles, in contrast to the hyperintensity in the quadriceps muscles (arrow) on a short tau inversion recovery (STIR)-weighted sequence (right). (B) Follow-up MRI shows an axial T1-weighted sequence (left) with thigh muscle atrophy and fatty infiltration. The axial STIR-weighted sequence (right) depicts persistent muscle edema (arrow). (C) Gomori trichrome stain shows a dystrophic pattern with the presence of intracytoplasmic aggregates (arrows). (D, E) Immunoperoxidase stains show the presence of endomysium CD8+ lymphocytes (arrowheads) (D) and CD68+ macrophage infiltrates (arrows) (E). (F) A menadione nitro-blue-tetrazolium (NBT) stain shows reducing bodies (arrowheads). Bar: $50 \mu \mathrm{m}$.

most common form of IIM in childhood is juvenile dermatomyositis, followed, less frequently, by overlap myositis and juvenile polymyositis. ${ }^{1}$ Over the past few years, several cases of anti-HMGCR necrotizing myopathy have been described in children, some of them presenting with subacute onset, but others with chronic evolution, mimicking $\mathrm{MD} .^{2}$ Genetic muscle diseases can also resemble inflammatory myopathy, with rapid clinical deterioration and inflammatory infiltrates on the muscle biopsy, such as limb-girdle $\mathrm{MD}$ caused by variants in the dysferlin, anoctamin-5, and fukutin-related proteins. ${ }^{3}$ Therefore, an overlap of clinical presentations can occur, which makes it challenging at times to differentiate IIM and inherited myopathies in diagnosis.

RBM is a rare muscle disorder, characterized by progressive weakness and the presence of cytoplasmic aggregates that reduce NBT in the muscle fibers (reducing bodies), caused by mutation on FHL1. ${ }^{4,5}$ Variants in FHL1 follow, in general, an X-linked dominant mechanism. There is no male-to-male transmission; females and males are affected, but males carrying the same variant are more severely affected, although very symptomatic females with early-onset disease have been reported. ${ }^{6}$

We present a girl with subacute onset of generalized weakness, accompanied by diffuse edema in the muscle MRI and inflammatory reaction on the muscle histology. IIM was the main hypothesis. At that time, the presence of intracytoplasmic aggregates in some fibers was not valued, and immunosuppressive treatment was initiated, resulting in significant improvement, which reinforced the original idea of inflammatory myopathy. However, the patient's worsening after an initial response to the treatment raised the possibility of genetic muscle disease. This motivated a new muscle MRI, which showed a degenerative progression to atrophy and fat substitution, and the reevaluation of the muscle biopsy, with characterization of reducing bodies. The occurrence of protein aggregates in the muscle fibers demands additional stains, such as menadione-NBT, which, if positive, indicates the $\mathrm{RBM}$ diagnosis. Whole exome sequencing must be done in this context to elucidate the molecular diagnosis. In our case, a variant in the FHL1 gene was found.

FHL1 (Four-and-a-Half-LIM domains 1) is a member of a group of proteins containing LIM domains, which are structural domains, composed of highly conserved sequences of 2 contiguous cysteine-rich zinc finger motifs, required for the fold and stability of each LIM domain. ${ }^{6}$ The FHL1 protein is involved in signaling processes, differentiation, and maintaining of structural elements, such as the sarcomere. ${ }^{5,6}$ Our patient presented a variant causing a change in the position 101, from the highly conserved cysteine by tyrosine, in the second LIM domain of the protein, affecting the protein zinc finger motif. ${ }^{5,7}$ 
The variant is absent in population databases, such as Gnomad and 1000 Genomes, and is predicted to be pathogenic in computational in silico analysis. The variant was not detected in the patient's parents, which confirms its pathogenicity.

Our case and other reports suggest that FHL1 might determine a phenotype resembling IIM. Schessl et al. ${ }^{7}$ presented detailed clinical and molecular characterizations of RBM. One of their patients was a girl with generalized weakness who was initially treated for myositis with immunoglobulin and prednisone, although the histology of that case was not available. Other authors have described inflammation in patients with FHL1 myopathies. Schreckenbach et al. ${ }^{8}$ described a patient with FHL1 myopathy with increased macrophage reaction on the muscle biopsy. Tanboon et al. ${ }^{9}$ described a boy with weakness initiated at 4 years old, a very high serum CK level, and endomysial inflammatory cell infiltration, mainly macrophages, that had an FHL1 pathogenic variant and concomitant anti-HMGCR antibody. In that case, differently from pediatric patients with positive anti-HMGCR who respond to immunotherapies, the patient with a concomitant FHL1 variant and IMNM did not improve with the treatment. Thus, FHL1-related myopathies could determine a phenotype similar to IMNM but refractory to the treatment, which is a red flag in terms of proceeding with a genetic test.

The other aspect of the connection of FHL1 and inflammatory myopathies is even more intriguing. Albrecht et al. ${ }^{10}$ demonstrated the development of anti-FHL1 autoantibodies in onefourth of patients with IIM and correlated their presence with a more severe disease. In that study, the sera of 141 patients with IIM were evaluated; $25 \%$ presented anti-FHL1 antibodies, and their muscle tissue had altered expression of the FHL1 protein, demonstrating a pattern similar to that found in patients with genetic RBM. They also demonstrated in vitro that granzyme$\mathrm{B}$, a protease that could lead to neoepitope generation, might cleave the FHL1 protein, triggering a secondary immunity. Furthermore, they showed that immunization of myositisprone mice with FHL1 exacerbated the muscle weakness and the inflammation in the muscle, indicating that immunity to FHL1 could contribute to tissue damage, and this protein might be a central autoantigen that leads to inflammatory myopathy. Hence, the presence of abnormal protein in the aggregates of RBM might initiate an autoimmune reaction and justify the findings seen in our patient, although the relationship between the mutation effect and the autoimmunity development is not clear. We could not test this antibody in our patient.

Immunosuppression and immunomodulation treatments are the standard approach to IIM and commonly prescribed when there is a high suspicion, even without a defined diagnosis. Our patient presented an initial response, recovering functional abilities such as head control and sitting ability. This transient improvement was followed by refractory clinical deterioration. Considering the possible autoimmunity mechanism involved in FHL1-related myopathy, it would be reasonable to conduct a trial of early immunosuppressive treatment to relieve the disease progression in these patients. Further prospective and larger studies could clarify and offer guidance regarding this approach for FHL1 patients.

Severe myopathy with rapid progression and diffuse muscle edema in children might not be an inflammatory myopathy, even with initial response to immunosuppressors, and FHL1related myopathy must be considered a differential diagnosis in this phenotype.

\section{Acknowledgment}

The authors thank the patient and her parents for participating in this study.

\section{Study Funding}

No targeted funding reported.

\section{Disclosure}

The authors report no disclosures relevant to the manuscript. Go to Neurology.org/ $\mathrm{N}$ for full disclosures.

Appendix Authors

\begin{tabular}{lll}
\hline Name & Location & Contribution \\
\hline André & Faculdade de Medicina da & Study concept, acquisition \\
Macedo & Universidade de São & and analysis of data, \\
Serafim & Paulo (FMUSP), Brazil & $\begin{array}{l}\text { literature review, and initial } \\
\text { Silva, MD }\end{array}$ \\
\end{tabular}

Clara Gontijo Faculdade de Medicina da Study concept, acquisition Camelo, MD Universidade de São and analysis of data, Paulo (FMUSP), Brazil literature review, and initial draft of the paper

\begin{tabular}{lll}
\hline Ciro Matsui- & Faculdade de Medicina da & $\begin{array}{l}\text { Acquisition and analysis of } \\
\text { Júnior, MD } \\
\text { Universidade de São } \\
\text { Paulo (FMUSP), Brazil }\end{array}$ \\
$\begin{array}{ll}\text { critical revision of } \\
\text { manuscript for intellectual } \\
\text { content }\end{array}$
\end{tabular}

\begin{tabular}{lll}
\hline Rodrigo de & Faculdade de Medicina da & $\begin{array}{l}\text { Acquisition of data, } \\
\text { Holanda }\end{array}$ \\
Mendonça, & Universidade de São & $\begin{array}{l}\text { literature review, and } \\
\text { critical revision of }\end{array}$ \\
MD & & $\begin{array}{l}\text { manuscript for intellectual } \\
\text { content }\end{array}$
\end{tabular}

\begin{tabular}{lll}
\hline Lúcia Maria & Faculdade de Medicina da & $\begin{array}{l}\text { Acquisition of data, } \\
\text { Campos, MD, }\end{array}$ \\
$\begin{array}{l}\text { Universidade de São } \\
\text { PhD }\end{array}$ & $\begin{array}{l}\text { literature review, and } \\
\text { critical revision of }\end{array}$ \\
& & $\begin{array}{l}\text { manuscript for intellectual } \\
\text { content }\end{array}$
\end{tabular}

Adriana Faculdade de Medicina da Acquisition of data,

Maluf Elias, Universidade de São literature review, and

MD, PhD Paulo (FMUSP), Brazil critical revision of manuscript for intellectual content

\begin{tabular}{lll}
\hline $\begin{array}{l}\text { Clovis Artur } \\
\text { Silva, MD, } \\
\text { PhD }\end{array}$ & $\begin{array}{l}\text { Faculdade de Medicina da } \\
\text { Universidade de São } \\
\text { Paulo (FMUSP), Brazil }\end{array}$ & $\begin{array}{l}\text { Acquisition of data, } \\
\text { literature review, and } \\
\text { critical revision of } \\
\text { manuscript for intellectual } \\
\text { content }\end{array}$ \\
\hline $\begin{array}{l}\text { Umbertina } \\
\text { Monti Reed, }\end{array}$ & Faculdade de Medicina da & $\begin{array}{l}\text { Acquisition of data, } \\
\text { literature review, and } \\
\text { critical revision of } \\
\text { manuscript for intellectual }\end{array}$ \\
& Paulo (FMUSP), Brazil & $\begin{array}{l}\text { mantent } \\
\text { content }\end{array}$
\end{tabular}


Appendix (continued)

\begin{tabular}{lll}
\hline Name & Location & Contribution \\
\hline Edmar & Faculdade de Medicina da & $\begin{array}{l}\text { Study concept, acquisition } \\
\text { Zanoteli, MD, }\end{array}$ \\
$\begin{array}{l}\text { Universidade de São } \\
\text { PhD }\end{array}$ & $\begin{array}{l}\text { and analysis of data, } \\
\text { literature review, and critical } \\
\text { revision of manuscript for } \\
\text { intellectual content }\end{array}$ \\
\end{tabular}

\section{References}

1. Rider LG, Nistala K. The juvenile idiopathic inflammatory myopathies: pathogenesis, clinical and autoantibody phenotypes, and outcomes. J Intern Med 2016;280:24-38.

2. Liang WC, Uruha A, Suzuki S, et al. Pediatric necrotizing myopathy associated with anti-3-hydroxy-3-methylglutaryl-coenzyme A reductase antibodies. Rheumatology 2017;56:287-293.
3. Benveniste O, Romero NB. Myositis or dystrophy? Traps and pitfalls. Presse Med 2011;40:e249-255.

4. Brooke MH, Neville HE. Reducing body myopathy. Neurology 1972;22:829-840.

5. Schessl J, Zou Y, McGrath MJ, et al. Proteomic identification of FHL1 as the protein mutated in human reducing body myopathy. J Clin Invest 2008;118: 904-912.

6. Bertrand AT, Bönnemann CG, Bonne G. FHL1 myopathy consortium. 199th ENMC international workshop: FHL1 related myopathies, June 7-9, 2013, Naarden, The Netherlands. Neuromuscul Disord 2014;24:453-462.

7. Schessl J, Taratuto AL, Sewry C, et al. Clinical, histological and genetic characterization of reducing body myopathy caused by mutations in FHL1. Brain 2009;132: 452-464.

8. Schreckenbach T, Henn W, Kress W, et al. Novel FHL1 mutation in a family with reducing body myopathy. Muscle Nerve 2013;47:127-134.

9. Tanboon J, Sanmaneechai O, Charuvanij S, et al. Concurrent positive anti-3-hydroxy3-methylglutaryl-coenzyme a reductase antibody with reducing body myopathy: possible double trouble. Neuromuscul Disord 2019;29:543-548.

10. Albrecht I, Wick C, Hallgren $\AA$, et al. Development of autoantibodies against muscle-specific FHL1 in severe inflammatory myopathies. J Clin Invest 2015;125. $4612-4624$ 


\section{Neurology}
Child Neurology: A Case of $\boldsymbol{F H L 1 - R e l a t e d ~ D i s e a s e ~ P r e s e n t i n g ~ a s ~ I n f l a m m a t o r y ~}$ Myopathy
André Macedo Serafim Silva, Clara Gontijo Camelo, Ciro Matsui-Júnior, et al. Neurology 2021;96;e1383-e1386 Published Online before print December 23, 2020

DOI 10.1212/WNL.0000000000011320

This information is current as of December 23, 2020

\section{Updated Information \&} Services

References

Subspecialty Collections

Permissions \& Licensing

Reprints including high resolution figures, can be found at: http://n.neurology.org/content/96/9/e1383.full

This article cites 10 articles, 1 of which you can access for free at: http://n.neurology.org/content/96/9/e1383.full\#ref-list-1

This article, along with others on similar topics, appears in the following collection(s):

\section{All Neuromuscular Disease}

http://n.neurology.org/cgi/collection/all_neuromuscular_disease Muscle disease

http://n.neurology.org/cgi/collection/muscle_disease

Information about reproducing this article in parts (figures,tables) or in its entirety can be found online at:

http://www.neurology.org/about/about_the_journal\#permissions

Information about ordering reprints can be found online:

http://n.neurology.org/subscribers/advertise

Neurology ${ }^{\circledR}$ is the official journal of the American Academy of Neurology. Published continuously since 1951, it is now a weekly with 48 issues per year. Copyright @ 2020 American Academy of Neurology. All rights reserved. Print ISSN: 0028-3878. Online ISSN: 1526-632X.

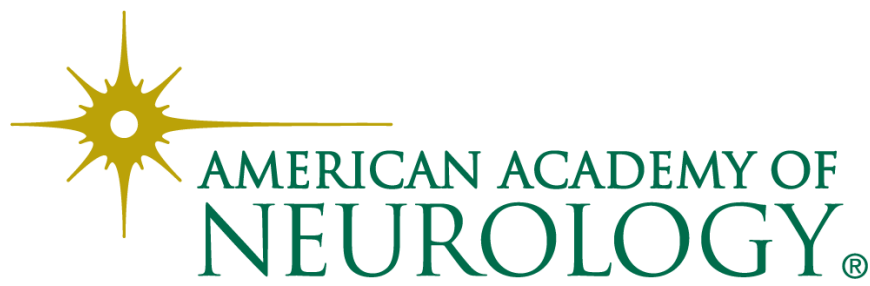

